Research Article

Kadhim Raheim Erzaij*, Wadhah A. Hatem, and Baydaa Hussain Maula

\title{
Applying Intelligent Portfolio Management to the Evaluation of Stalled Construction Projects
}

https://doi.org/10.1515/eng-2020-0064

Received Apr 03, 2020; accepted May 19, 2020

\begin{abstract}
Much research in the construction industry is based on the concept of a unique project; hence, such concepts (or philosophy) present the construction project as a unit of analysis for the entire completion process that is usually delivered independently. Most decision support tools in construction have been designed at the project level rather than for construction institutions that often implement many projects simultaneously. Typically, these projects have common objectives that create dependencies among them. Then, the success of one project depends on other projects and the existing interrelationships among them. Thus, construction institutions still need to deal with their projects from a portfolio perspective, which requires strategic management at a portfolio level. This paper employs resource management techniques to allocate resources to manage construction portfolios. A case study targeted strategic decision making about financing projects that have stalled. The final recommendation of this paper is to use development and planning software to serve and support strategic decisions in institutions with concurrent stalled projects.
\end{abstract}

Keywords: Intelligent portfolio management, modern portfolio theory, allocated budget projects, unnamed budget projects, intelligent management for construction portfolios

\section{Introduction}

Investment professionals have become specialised, and financial concepts have become more sophisticated, over

\footnotetext{
*Corresponding Author: Kadhim Raheim Erzaij: Department of Civil Engineering, College of Engineering, University of Baghdad, Baghdad, Iraq; Email: kadhim69@coeng.uobaghdad.edu.iq Wadhah A. Hatem: Baquba Technical Institute, Middle Technical University, Iraq , Baghdad

Baydaa Hussain Maula: Institute of Technology-Baghdad, Middle Technical University, Baghdad, Iraq
}

the past 25 years, allowing higher quality client service and better investment performance.

When construction organisations invest in a variety of projects, these combinations of construction projects can be considered portfolios of construction projects. Concepts of intelligent portfolio management (IPM) can be applied to a portfolio of construction projects. A portfolio of diversified projects usually has less risk than individual projects. However, investment in construction projects differs from that in other sectors. These differences arise from the difficulty of applying the portfolio theory in the construction industry [1].

Although academic consideration of the construction industry has been based on the delivery of one project, management focus has recently shifted from a single project to managing a portfolio of projects to achieve strategic objectives. A portfolio approach requires a holistic analysis of the projects undertaken simultaneously. The concept of portfolio management (PM) is based on the fact that a duration estimate and a financial budget are needed for every project in the construction industry, whether it is a new development or maintenance work for an existing facility [2].

A previous studies were used to develop mathematical models that will be applied to the construction projects. The outcomes display that the PSO technique is proper for evaluating project management problems and can be utilized as a useful tool to search the optimal solutions with differs parameters [3].

Currently, in all Iraqi buildings, it was adopting a corrective maintenance approach in maintaining building rather than proper maintenance management approaches (preventive, predictive), this affects negatively on the quality and cost of building maintenance. In addition, lack of proper and specific maintenance-related documentation methods. The study proposed approach to develop the building maintenance management by using deterioration models which consist of different routes [4].

Researchers develop a clear concept about the BIM adoption in Iraq through investigating potential benefits that can be obtained through its application in construc-

¿ open Access. (c) 2020 K. R. Erzaij et al., published by De Gruyter. (Cc) BY 4.0 License 
tion projects also build a measurement model for these benefits [5, 6].

Management of a project plays a critical role for investment professionals and investors and in success in the construction industry. As one of the most important methods of management, the principles of PM have been around for about 20 years [7]. Therefore, choosing a successful management technique plays a key role in completing projects [8]. The vital role of PM is to optimise resource allocation of projects within the portfolio to achieve the technology and financial objectives of the institution. The theory of PM is a normative theory that describes the standard or norm of behaviour that investors should pursue when developing a construction portfolio.

Though widely applicable, modern portfolio theory (MPT) has a stronger influence when practised in PM. In its simplest form, MPT provides a framework to predict the performance of select projects within portfolios and to determine the probability of investment risk. In the investment management field, MPT introduces new terminology. Portfolio management theory (PMT) provides a framework to specify and measure the investment risk of projects within a portfolio. In addition, PM develops relationships among expected asset returns and investment risks [9].

IPM aims to optimise the selection of investment projects by defining the strategic objectives of an institution. This selection achieves an ideal balance among projects. The dependencies in construction portfolio

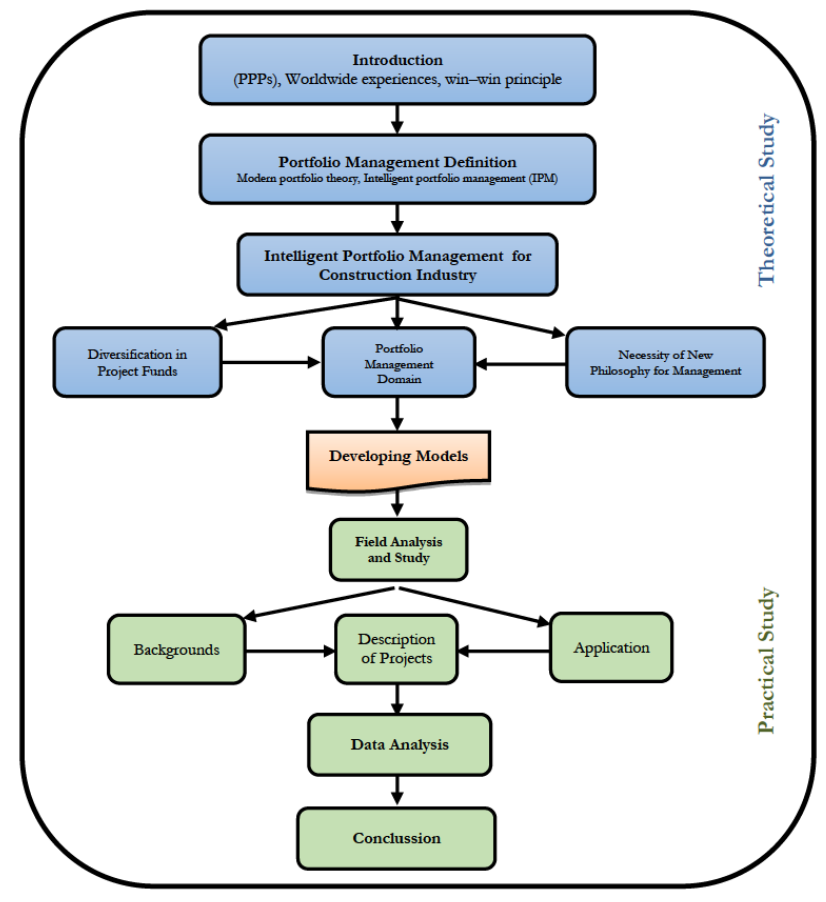

Figure 1: Flowchart of the research methodology. projects within an institution must be considered because they have a significant effect on portfolio success. Few studies in construction PM investigate how the dependencies between projects can be handled [10].

The researcher studied the stalled projects to assess poject's completion acceleration before and after the crisis (scarcity of financial resources). Situations of governmental investment plan projects also was studied from 2015 to 2018. Then the researcher summarized the financial statements for a group of suspended projects, each according to its sector (which will represent the financial portfolios later) over four years.

After filed data was collected, analysis was done. Finally, results were discussed in light of Iraqi construction industry. as given the flow chart below. Figure 1 summarizes the steps followed in this research.

\section{Portfolio Management Definition}

Portfolio management is a decision process to prepare lists of investment projects that need to be constantly revised, updated, evaluated, and prioritised. Generally, PM is an uncertain process with continuous changes in information. It is characterised by strategic considerations through multiple objectives and interdependencies among portfolio projects [11].

$\mathrm{PM}$ is a decision process comprising several decisionmaking processes within institutions through periodic reviews of all portfolio projects. Which projects require new institutional selection strategies and new resourceallocation decisions can be determined through the analysis of the set of projects compared against each other [11]. Moreover, PM is vital for successful project innovation. The $\mathrm{PM}$ process ranges from strategic choices for resources and technologies needed to execute construction portfolios to how institutions spend scarce engineering, financial and marketing resources to deliver results. PM deals with the balance between the adequate number of projects that should be done and the available resources or capabilities of institutions [12]. Thus, PM considers the manifestation of the institutional strategy to explain or dictate where and how institutions invest in the future. Construction PM treats investment projects as financial investments like a fund manager treats stocks [12].

In addition, PM deals with achieving the strategic investment of a portfolio aligned with the overall institutional strategy. This alignment can be accomplished by maximising the portfolio value and investment return and balancing priorities in the portfolios. The successful per- 
formance of institutions requires managing the execution priority of projects within the portfolio. This step is vital for the following reasons [13]:

- Senior management can achieve strategic institutional objectives for various types of implemented projects using the PM methodology.

- The type of construction projects selected and the execution technology determine the institution's allocations for the next five years.

- Construction PM is about the allocation of scarce engineering, financial, and operational resources.

- PM addresses the critical issue of balancing the available or scarce resources.

- For the construction industry in Iraq, doing many projects with limited available resources results in a longer execution cycle and poor quality or underperforming projects.

Construction institutions increasingly take on projects to achieve firm objectives more efficiently and to augment their number of projects. These additional projects create the need for the intelligent management of construction portfolios to plan for a multitude of synchronous projects in an institution. Therefore, PM is not uniform and must be adapted to the institutional situation and the responsibilities and roles of institutional managers [14].

Studies conducted by the Project Management Institute (PMI) have reviewed the practices for PM and investigated the results of multiple methods. The findings demonstrate that high-performance institutions usually apply PM methodologies. These PM methodologies may be applied to processes, tools, or manager responsibilities that arose to address the complex requirements of the construction environments. This situation is very different at lowperforming institutions [15].

Project management should be a part of PM, especially when related to corporate governance. Therefore, PM should have approaches to settle contract requirements. According to the Project Management Association, PM is a framework or structure that should comprise the following [15]:

- portfolio direction effectiveness,

- project sponsorship efficiency,

- project management performance, and

- disclosure and reporting.

In addition, PM can be divided into two parallel perspectives. The first perspective concerns interrelationships among various similar projects. The requirements for project management require investigation to acquire the overall objectives of the institution. The second perspec- tive is adopting the correlation of various project objectives to maximise the outcomes of combination projects, which led to developing the concept of the portfolio. The PMI defines 'portfolio' as a group of related programmes, processed in close coordination to achieve high control and more efficient performance, which may not occur when processing them individually [16]. The development of PM techniques defines the centralised management of one or more portfolios by identifying, prioritising, managing, and controlling the projects to achieve specific strategic institutional objectives. Indeed, the portfolio theory can be comprehended as the integration of similar projects grouped to facilitate effectively reaching the strategic objectives of an institution. Portfolio theory is not necessarily interdependent or directly related to the projects of a construction portfolio [16].

\section{Necessity of New Philosophy for Management}

Strategic management is considered a monopoly of top management, whereas the management of a project issue is the responsibility of project management. This perspective fails to perfect the interactive relationships between both fields, especially in project-based industries. Initially, functioning strategic management is considered a precondition for aligning the evaluated project with the portfolio. Thus, the PM process may be essential for executing the institution's formulated objectives [17]. Some characteristics of the construction industry must be considered when using strategic management. More than other sectors, the construction industry has been slow to adopt new strategic management methods, and these adoptions require many considerations [18].

First, the base institutional model for construction portfolio projects is an obstacle when a temporary institution (individual projects) does not allow the implementation of complex strategies. Some studies have found that medium-sized construction institutions are less likely to implement strategic management practices. Such institutions are less concerned about strategic management and are more proactive towards one-unit production [19]. The educational backgrounds of managers of construction institutions have led them to be less aware of the role of strategic management because most construction enterprises require an engineering background. Many of these managers lack formal training about formulating and implementing strategic management methods [20]. 
Research into strategic management methods for construction continues, despite the delayed acceptance of the portfolio theory in construction management. While the changing strategy formulation has received more attention, the mechanism for implementing the developed strategies in the construction industry is still poorly researched.

The rapid acceleration of urbanisation requires the construction industry to adopt a new management method. Traditional project management cannot handle the complexity of some construction projects. Thus, new management methods are needed to achieve several objectives [21]:

- to integrate the activities of construction organisations during project realisation,

- to achieve more added value in service markets in the construction industry,

- to diversify financing sources in construction projects,

- to achieve high-performance standards for underperforming projects,

- to find raw materials and modern technologies in the construction industry,

- to interact with authorities and suppliers throughout all construction phases of a project.

The reasons above are the result of the complexity of the organisational structure in the construction production process and its development as an independent economic entity. Modern computing techniques monitor construction activities to promote efficiency, and institutional departments coordinate employees and activities with other institutions. However, opportunities and the capacities of the construction industry are restrained because institutional construction managers lack construction PM skills owing to the following [22]:

- Construction managers prefer to work in the traditional planning economy.

- Construction institution owners must employ a construction project management specialist with a civil engineering degree.

- The educational system must focus on preparing highly skilled narrow-specialisation engineers.

PMT addresses more extensive tasks, including integrating interactions between design teams and subcontractors involved in the same project and organising building operations owned by several stockholders. Figure 2 summarises the differences between the two strategic management methodologies.

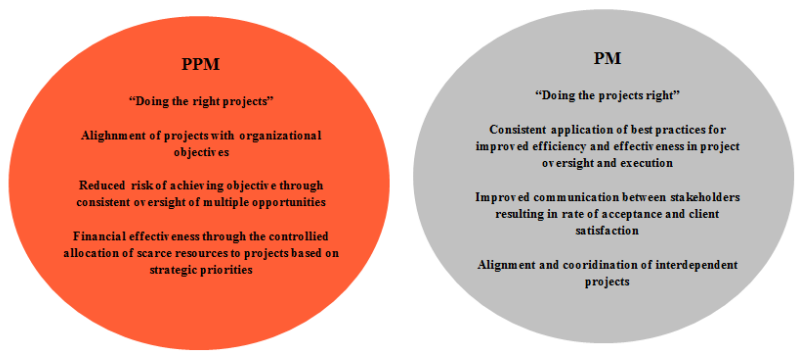

Figure 2: Differences between productive management methods in the construction industry [23] PPM: Project portfolio management; PM: project management

\section{Portfolio Management Domain}

The essential purposes of PMT are to achieve a relatively lofty investment return rate $(\mathrm{R} \%)$ for the level of specified tasks or the lowest possible risk for a specified investment return rate. Risks may include the probability that the actual return $(\mathrm{r} \%)$ is less than the expected return $(\mathrm{R} \%)$, where the risk and return usually have a logical correlation (i.e. increasing investment returns result in greater risks [14]). The environment of PM must be combined with computer technology that makes financial information sources accessible throughout the institution. In addition, PM enables senior institutional managers to make more efficient decisions.

Construction PM is linked to the implementation of strategy in two ways. First, management strategies for implementing projects have been studied extensively. Second, PM practices are developed by modifying top management strategies. This concept can be applied for single and multiple management projects, specifically in projectbased industries, such as the construction industry, where projects have paramount strategic relevance [22]. Intelligent construction PM (ICPM) is a method of selecting and managing institutional projects using risk factors and the return rate. While the techniques originated in the financial industry, they can be applied to the evaluation of a construction project portfolio. The MPT targets a broader set of activities (e.g. the selection of projects, controlling resources, continuous risk management, and reporting a wider range of factors). Construction portfolios are different from others in terms of the subprojects that have shared objectives but compete for allocated resources and strategic assets [24].

The essential tasks of PM include investigating the suitable available projects, selecting and prioritising projects based on the resources, and evaluating the running process concerning meeting portfolio requirements. 
Such activities typically involve an optimisation technique and algorithm management for specific project selection criteria. However, project selection criteria are the most important means of aligning PM strategies; thus, criteria deserve the attention of practitioners, researchers and scholars [25]. The prediction of progress for individual construction projects is a complex process because of the uncertain and unique nature of the construction industry. The selection of project packages in a portfolio must be rearranged when the risk profile of a project changes after its initiation. The initial risk evaluation and continued information updates in a portfolio lead to high-performance project progress. This improved outcome may be the main motivation for the development of strategic management, such as PM, in institutions [26].

\section{Diversification in Project Funds}

An intuitive premise in the construction industry is providing sufficient reasonable information from the viewpoint of the contractor before negotiating the decision about the execution of a project [10]. Given the difficulties of acquiring and evaluating information for similar projects in the construction and industrial world, investment institutions have adopted PM. Institutions use PM to monitor the portfolios under construction, instead of simply selecting projects for the portfolios [18].

Debt and equity are the two primary capital sources for funding a new product or project. Debt capital represents borrowing assets from outside the institution. Capital should be repaid at a pre-agreed interest rate on an agreed schedule. Debt funding may represent capital borrowed via mortgages, loans, or bonds, with a risk that the borrower cannot repay the borrowed funds. In such a case, the lender's profits are shared using revenues. Outstanding debt is usually listed in the liabilities section on the balance sheet [26]. Equity capital is 'corporate money comprised of funds of owners and retained earnings. Owners' funds are further classified as common and preferred stock proceeds or owners' capital for a private (non-stockissuing) company. Retained earnings are funds previously retained in the corporation for capital investment'. Equity is usually listed in the section on the net worth on the balance sheet [26].

In IPM, construction institutions must control the product pack (projects) in a portfolio regularly in addition to allocating assets and resources. Allocation of resources can be determined using a priority system for implementing the projects within the portfolio to meet the expecta- tions of the strategic asset allocation or the available resources. Controlling a product pack also requires a comprehensive monitoring process to provide detailed information for the financial situation of the organisation. Rearranging the asset allocation strategy is a consequence of monitoring and controlling processes, which might cause several changes at the resource-allocation level of the projects. Management of a portfolio is a comprehensive asset management process characterised by changes. Institutions regularly update their decisions as a response to the circumstances [6]. The application of PM in the construction industry requires a huge amount of information regarding the financial performance of institutions that top management must effectively understand to make wise decisions.

'Do not put all of your eggs in one basket' is conventional wisdom in the investment world. In technical terms, this aphorism addresses diversification benefits. Moreover, MPT quantifies the concept of diversification by introducing a statistical association for the covariance or dependence between combined units. It is important to prioritise the execution of projects in a construction institution that may become bankrupt, especially when organisational resources are limited [27]. The concept of diversification is intuitive and applies to many different fields within finance. Applying the concept of diversification and introducing a new method of obtaining improved estimates of variances and covariances allows for a more precise measure of diversification and a more careful measure of risk [27].

\section{Field Analysis and Study}

The construction industry in Iraq has undergone many changes, emergencies, and modifications over the past decade, and building remains remain largely dependent on state treasury funding. A high proportion of the Iraqi budget and gross domestic product (GDP) consists of oil revenue. The Global Financial Crisis affected many countries, especially oil-producing countries and their military circumstances. These factors led to the end of Iraqi infrastructure projects that provided necessities for society's demands, needs, and advancement. The financial crisis prompted the investigation and employment of modern techniques to manage the financing of construction projects that stalled five years ago. First, the researcher studied the stalled projects to assess project completion acceleration before and after the crisis (scarcity of financial resources). Governmental investment plan projects 
Table 1A: Situations of Investment Plan Projects for 2015 to 2018*

\begin{tabular}{|c|c|c|c|c|c|c|c|c|c|c|}
\hline \multirow[t]{2}{*}{ Sector Name } & \multicolumn{5}{|c|}{2015} & \multicolumn{5}{|c|}{2016} \\
\hline & 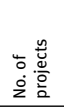 & 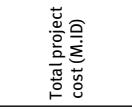 & 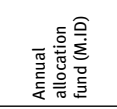 & 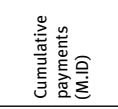 & 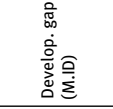 & 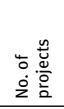 & 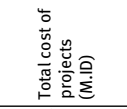 & 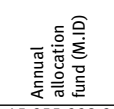 & 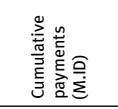 & 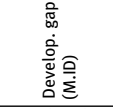 \\
\hline Industry Sector & 395 & $112,138,047.7$ & $17,270,175.7$ & $41,865,925.8$ & $70,272,121.9$ & 247 & $109,613,353.6$ & $15,955,998.9$ & $51,147,791.8$ & $58,465,561.7$ \\
\hline Agriculture Sector & 195 & $23,921,995.8$ & $477,181.0$ & $6,488,768.60$ & $17,433,227.2$ & 129 & $22,680,212.9$ & $174,832.24$ & $4,757,680.4$ & $17,922,532.5$ \\
\hline Buildings \& Services & 1,744 & $86,028,583.6$ & $11,686,909.6$ & $23,888,791.0$ & $62,139,792.6$ & 1,225 & $59,040,816.1$ & $3,421,176.7$ & $21,632,512.4$ & $37,408,303.8$ \\
\hline Transportation Communication & 371 & $27,579,131.9$ & $1,447,967.9$ & $5,525,323.3$ & $22,053,808.6$ & 241 & $21,799,679.2$ & $370,479.8$ & $4,931,919.4$ & $16,867,759.7$ \\
\hline Programme Province Investment & 3,830 & $37,652,679.8$ & $4,338,654.8$ & & - & 3,170 & $33,479,428$ & $1,818,274$ & का & - \\
\hline Total & 6,535 & $287,320,439.0$ & $30,220,889.0$ & $77,768,808.7$ & $171,898,951$ & 1,842 & $213,134,062$ & $19,922,487$ & $82,469,904$ & $130,664,158$ \\
\hline
\end{tabular}

Table 1B: Situations of Investment Plan Projects for (2015-2018)*

\begin{tabular}{|c|c|c|c|c|c|c|c|c|c|c|}
\hline \multirow[t]{2}{*}{ Sector Name } & \multicolumn{4}{|c|}{2015} & \multirow[b]{2}{*}{ 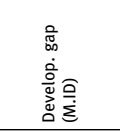 } & \multirow[b]{2}{*}{ 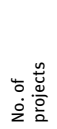 } & \multicolumn{3}{|c|}{2016} & \multirow[b]{2}{*}{ 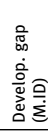 } \\
\hline & 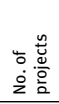 & 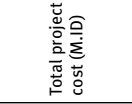 & 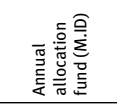 & 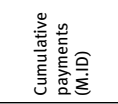 & & & 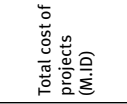 & 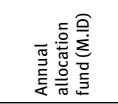 & 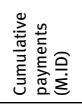 & \\
\hline Industry Sector & 256 & $114,774,070.4$ & $17,997,140.6$ & $42,010,073.3$ & $72,763,997.2$ & 232 & $112,047,708.7$ & $17,318,102.4$ & - & $\cdot$ \\
\hline Agriculture Sector & 105 & $12,635,586.92$ & $520,835.92$ & $4,930,214.13$ & $7,705,372.79$ & 108 & $12,724,845.95$ & $4,460,371.2$ & - & - \\
\hline Buildings \& Services & 1,086 & $60,548,886.80$ & $4,791,785.09$ & $23,363,911.5$ & $37,184,975.3$ & 1,009 & $52,001,945.81$ & - & - & - \\
\hline Transportation Communication & 237 & $16,488,318.16$ & $488,069.00$ & $4,709,600.56$ & $11,778,717.2$ & 231 & $16,384,551.76$ & - & - & - \\
\hline Programme Province Investment & 3,039 & $27,868,265.1$ & & & & 2,743 & $25,711,664.3$ & - & - & - \\
\hline Total & 4,723 & $232,315,127.0$ & $23,797,830.6$ & $75,013,799.5$ & $129,433,063$ & 4,323 & $218,870,716.5$ & $21,778,473.6$ & - & - \\
\hline
\end{tabular}

Table 2: Expected Iraqi Oil Production and Revenues

\begin{tabular}{|c|c|c|c|c|c|}
\hline Year & $\begin{array}{l}\text { Oil production } \\
\text { million }(\mathrm{bbl} . / \mathrm{d})\end{array}$ & $\begin{array}{l}\text { Oil export million } \\
(\mathrm{bbl} / \mathrm{d})\end{array}$ & $\begin{array}{l}\text { Expected oil revenues per IMF } \\
\text { (B.ID) }\end{array}$ & $\begin{array}{l}\text { Expected oil revenues per } \\
\text { Ministry of Oil (B.ID) }\end{array}$ & $\begin{array}{l}\text { Expected oil revenues per Budget } \\
\text { Strategy Committee (B.ID) }\end{array}$ \\
\hline 2018 & 4.7 & 3.9 & 75045 & 75715.9 & 74033.4 \\
\hline 2019 & 4.7 & 3.9 & 74537 & 75715.9 & 74033.4 \\
\hline 2020 & 4.7 & 3.9 & 76055 & 75715.9 & 74033.4 \\
\hline 2021 & 4.9 & 4.0 & 77232 & 94914.9 & 74033.4 \\
\hline 2022 & 4.9 & 4.0 & 79076 & 103543.2 & 74033.4 \\
\hline Total & 23.9 & 19.7 & 381940 & 425605.5 & 370167 \\
\hline
\end{tabular}

*Source: Ministry of Planning - National Development Plan (2018-2022) IMF: International Monetary Fund

Table 3: Expected Miscellaneous Income*

\begin{tabular}{ccccc}
\hline Year & Direct taxes & Indirect taxes & Other & Total \\
\hline 2018 & 4996.6 & 2213.7 & 5799.8 & 14923.9 \\
2019 & 5146.1 & 2313.1 & 6038.4 & 14430.4 \\
2020 & 5303.4 & 2390.7 & 6262.4 & 13956.5 \\
2021 & 5466.5 & 2471.6 & 6492.3 & 13497.6 \\
2022 & 5639.8 & 2555.8 & 6728.3 & 13009.7 \\
\hline *Source: Ministry of Planning - National Development Plan (2018-2022)
\end{tabular}

*Source: Ministry of Planning - National Development Plan (2018-2022)

were also studied from 2015 to 2018. Then the researcher summarized the financial statements for a group of suspended projects, each according to its sector (which will represent the financial portfolios later) over four years. Investment budget projects and their costs, adjusted allocations, and cumulative expenditure in the government sector from 2015 to 2018 are shown in the following tables. The data were extracted from unified annual reports on the follow-up of investment budget projects. According to the implementing agencies, 'Amounts [are] in millions of dinars (M.ID), and [the] information represents [the] last update on (15/Mar./2020) [15 March 2020]. [The] Iraqi Ministry of Planning (MOP) [has] also launched a National Development Plan (NDP) for the next five years (2018-2022)'. Ta- ble 1A\&1B summarises some financial data for the stalled projects.

In another endeavour, the researcher investigated the financial inputs' expectations of the federal budget, based on estimates of some federal financial authorities, such as the IMF, the Ministry of Oil and the Budget Strategy Committee. Tables 2 to 4 illustrate expectations of financial inputs from oil production, oil export, and non-oil proceeds for the next five years.

Target growth rates of investments in the national economy for each sector as envisaged by successive governments are shown in Tables 5 to 7. National development plans established the targeted growth rates for each sector in line with the expectation of financial inputs over the next five years. Based on the above, the total amounts that can be spent on each sector are shown below. The researcher summarized the targeted growth rates for each sector in Tables 5 to 7.

The portfolios of the stalled construction projects were named according to the state sectors: agricultural, energy, service, infrastructure, and other project portfolios. The portfolio in this study is a set of stalled projects that were suspended due to a lack of funding. Usually, projects in 
Table 4: Overall Expected Income

\begin{tabular}{|c|c|c|c|c|c|c|}
\hline \multirow[t]{2}{*}{ Year } & \multicolumn{3}{|c|}{ Expecte oil revenues (BID) } & \multicolumn{3}{|c|}{ Miscellaneous income (BID) } \\
\hline & International Monetary Fund & $\begin{array}{c}\text { Ministry of } \\
\text { Oil }\end{array}$ & Strategic Budget Committee & $\begin{array}{l}\text { Direct } \\
\text { taxes }\end{array}$ & $\begin{array}{c}\text { Indirect } \\
\text { taxes }\end{array}$ & Other \\
\hline 2018 & 75045 & 75715.9 & 74033.4 & 4996.6 & 2213.7 & 5799.8 \\
\hline 2019 & 74537 & 75715.9 & 74033.4 & 5146.1 & 2313.1 & 6038.4 \\
\hline 2020 & 76050 & 75715.9 & 74033.4 & 5303.4 & 2390.7 & 6262.4 \\
\hline 2021 & 77232 & 94914.6 & 74033.4 & 5466.5 & 2471.6 & 6492.3 \\
\hline 2022 & 79076 & 103543.2 & 74033.4 & 5639.8 & 2555.8 & 6728.3 \\
\hline Summary & \multirow{2}{*}{\multicolumn{3}{|c|}{370.2 (B.ID) $84.1 \%$}} & \multirow{2}{*}{\multicolumn{3}{|c|}{69.8 (B.ID) $15.9 \%$}} \\
\hline Total & & & & & & \\
\hline
\end{tabular}

Table 5: Target Growth Rates of Investments in National Economic Sectors from 2018 to 2022 *

\begin{tabular}{|c|c|c|c|c|c|c|c|c|c|}
\hline \multirow[t]{2}{*}{ Sector } & \multirow{2}{*}{$\begin{array}{l}2015 \text { base } \\
\text { year (B.ID) }\end{array}$} & \multirow{2}{*}{$\begin{array}{c}\text { Target } \\
\text { growth next } \\
\text { five years }\end{array}$} & \multirow{2}{*}{$\begin{array}{c}\text { Planned } \\
\text { investment } \\
\text { amount } \\
\text { (B.ID) }\end{array}$} & \multirow{2}{*}{$\begin{array}{c}\text { of } \\
\text { investment }\end{array}$} & \multicolumn{5}{|c|}{ Distribution of planned investments over five years (B.ID) } \\
\hline & & & & & 2018 & 2019 & 2020 & 2021 & 2022 \\
\hline Oil & 100929.2 & $7.5 \%$ & 84683.7 & $38.4 \%$ & 14579.5 & 15673 & 16848 & 18112 & 19470.5 \\
\hline Mining & 330.0 & $1.0 \%$ & 5677.2 & $1.0 \%$ & 1077.9 & 1105.9 & 1134.7 & 1164.2 & 1194.5 \\
\hline $\begin{array}{l}\text { Transformative } \\
\text { industries }\end{array}$ & 1535.1 & $10.5 \%$ & 4854.3 & $2.2 \%$ & 787.2 & 689.9 & 961.2 & 1062.2 & 1173.7 \\
\hline Infrastructure & 13768.4 & $6.8 \%$ & 12233.6 & $5.5 \%$ & 2135.8 & 2281.1 & 2436.2 & 2601.8 & 2778.8 \\
\hline $\begin{array}{c}\text { Transport and } \\
\text { communications }\end{array}$ & 14313.9 & $7.0 \%$ & 39582.1 & $17.9 \%$ & 6883.0 & 7362.8 & 7880.3 & 8431.9 & 9022.1 \\
\hline Trade & 14872.9 & $8.3 \%$ & 8545.1 & $3.9 \%$ & 14479.9 & 1568.0 & 1698.2 & 1839.1 & 1991.8 \\
\hline Insurance & 11815.1 & $2.6 \%$ & 1077.9 & $2.6 \%$ & 1077.9 & 1105.9 & 1134.7 & 1164.2 & 1194.5 \\
\hline Services sector & 19777.8 & $4.5 \%$ & 37219 & $16.9 \%$ & 6803.3 & 7109.5 & 7429.4 & 7763.7 & 8113.1 \\
\hline Non-oilactivities & 81402.0 & $6.1 \%$ & NA & NA & 98201.8 & 104255.3 & 110721.6 & 117631.5 & 125017.3 \\
\hline Total (B.ID) & 182331200 & $7.0 \%$ & 220640.0 & $100 \%$ & 38592.2 & 41172.8 & 43934.2 & 46889.4 & 50052.5 \\
\hline Total (B.\$) & 154090400 & $7.0 \%$ & 186465 & $100 \%$ & 32600 & 34800 & 37200 & 39700 & 42300 \\
\hline
\end{tabular}

^Data from Ministry of Planning - National Development Plan (2018-2022) NA: not available

Table 6: Target Growth Rates of the Gross Domestic Product (GDP) for (2018-2022)*

\begin{tabular}{|c|c|c|c|c|c|c|c|}
\hline \multirow[t]{2}{*}{ Sector } & \multirow{2}{*}{$\begin{array}{l}2015 \text { base year } \\
\text { (B.ID) }\end{array}$} & \multirow{2}{*}{$\begin{array}{l}\text { Target growth next } \\
\text { five years }\end{array}$} & \multicolumn{5}{|c|}{ Distribution of planned development - gross domestic product(B.ID) } \\
\hline & & & 2018 & 2019 & 2020 & 2021 & 2022 \\
\hline Agricultural & 3707.5 & $8.4 \%$ & 4722.5 & 5119.2 & 5549.2 & 6015.3 & 6520.6 \\
\hline Oil & 100929.2 & $7.5 \%$ & 125384.0 & 134787.5 & 144896.9 & 155764.2 & 167446.5 \\
\hline Mining & 330.0 & $1.0 \%$ & 340.0 & 343.4 & 346.8 & 350.3 & 353.8 \\
\hline $\begin{array}{c}\text { Transformative } \\
\text { industries }\end{array}$ & 1535.1 & $10.5 \%$ & 2071.2 & 2288.7 & 2529.0 & 2794.5 & 3088.0 \\
\hline Energy & 2130.7 & $6.0 \%$ & 2537.7 & 2690.0 & 2851.4 & 3022.4 & 3203.8 \\
\hline Infrastructure & 13768.4 & $6.8 \%$ & 16772.5 & 17913.0 & 19131.1 & 20432.0 & 21821.4 \\
\hline $\begin{array}{l}\text { Transport and } \\
\text { communication }\end{array}$ & 14313.9 & $7.0 \%$ & 17535.1 & 18762.6 & 20076.0 & 21481.3 & 22985.0 \\
\hline Trade & 14872.9 & $8.3 \%$ & 18892.1 & 20460.2 & 22158.4 & 23997.5 & 25989.3 \\
\hline Insurance & 11815.1 & $2.6 \%$ & 12760.8 & 13092.6 & 13433.0 & 13782.3 & 14140.6 \\
\hline Services sector & 19777.8 & $4.5 \%$ & 22569.8 & 23585.4 & 24646.7 & 25755.8 & 26914.9 \\
\hline Non-oil activities & 81402.0 & $6.1 \%$ & 98201.8 & 104255.3 & 110721.6 & 117631.5 & 125017.3 \\
\hline Total (B.ID) & 182331200.0 & $7.0 \%$ & 223585.8 & 239042.8 & 255618.5 & 273395.7 & 292463.8 \\
\hline Total (B.\$) & 154090400 & $7.0 \%$ & 189.2 & 202.2 & 216.3 & 231.3 & 247.4 \\
\hline
\end{tabular}

Table 7: Expected income [31]

\begin{tabular}{|c|c|c|c|c|c|c|}
\hline \multirow[t]{2}{*}{ Year } & \multicolumn{3}{|c|}{ Expected oil revenues (BID) } & \multicolumn{3}{|c|}{ Miscellaneous income (BID) } \\
\hline & International Monetary Fund & $\begin{array}{c}\text { Ministry of } \\
\text { Oil }\end{array}$ & Strategic Budget Committee & $\begin{array}{l}\text { Direct } \\
\text { taxes }\end{array}$ & $\begin{array}{c}\text { Indirect } \\
\text { taxes }\end{array}$ & Other \\
\hline 2018 & 75045 & 75715.9 & 74033.4 & 4996.6 & 2213.7 & 5799.8 \\
\hline 2019 & 74537 & 75715.9 & 74033.4 & 5146.1 & 2313.1 & 6038.4 \\
\hline 2020 & 76050 & 75715.9 & 74033.4 & 5303.4 & 2390.7 & 6262.4 \\
\hline 2021 & 77232 & 94914.6 & 74033.4 & 5466.5 & 2471.6 & 6492.3 \\
\hline 2022 & 79076 & 103543.2 & 74033.4 & 5639.8 & 2555.8 & 6728.3 \\
\hline
\end{tabular}


Table 8: Target growth rates for portfolios [32]

\begin{tabular}{|c|c|c|c|c|c|c|c|c|}
\hline \multirow[t]{2}{*}{ Portfolio* } & \multirow{2}{*}{$\begin{array}{c}\text { Target growth } \\
\text { next } 5 \text { years }\end{array}$} & \multirow{2}{*}{$\begin{array}{c}\text { Investment } \\
\text { planned (bID) }\end{array}$} & \multirow[t]{2}{*}{ Investment \% } & \multicolumn{5}{|c|}{ Distribution of planned investments over five years (BID) } \\
\hline & & & & 2018 & 2019 & 2020 & 2021 & 2022 \\
\hline P1 & $8.4 \%$ & 7574.2 & $3.4 \%$ & 1280.2 & 1388.4 & 1505.0 & 1631.5 & 1768.5 \\
\hline $\mathrm{P} 2$ & $7.5 \%$ & 84683.7 & $38.4 \%$ & 14579.5 & 15673 & 16848 & 18112 & 19470.5 \\
\hline P3 & $1.0 \%$ & 5677.2 & $2.6 \%$ & 1077.9 & 1105.9 & 1134.7 & 1164.2 & 1194.5 \\
\hline P4 & $10.5 \%$ & 4854.3 & $2.2 \%$ & 787.2 & 689.9 & 961.2 & 1062.2 & 1173.7 \\
\hline P5 & $6.0 \%$ & 20243.3 & $9.2 \%$ & 3591.1 & 3806.5 & 4034.9 & 4277.0 & 4533.7 \\
\hline P6 & $6.8 \%$ & 12233.6 & $5.5 \%$ & 2135.8 & 2281.1 & 2436.2 & 2601.8 & 2778.8 \\
\hline $\mathrm{P} 7$ & $7.0 \%$ & 39582.1 & $17.9 \%$ & 6883.0 & 7362.8 & 7880.3 & 8431.9 & 9022.1 \\
\hline P8 & $8.3 \%$ & 8545.1 & $3.9 \%$ & 14479.9 & 1568.0 & 1698.2 & 1839.1 & 1991.8 \\
\hline P9 & $4.5 \%$ & 37219 & $16.9 \%$ & 6803.3 & 7109.5 & 7429.4 & 7763.7 & 8113.1 \\
\hline
\end{tabular}

*Portfolios are coded for data organisation.

Table 9: Priority Matrix Assessment for Portfolios

\begin{tabular}{|c|c|c|c|c|c|c|c|c|c|}
\hline \multirow[t]{2}{*}{ Assessment Axes of Priority Matrix* } & \multicolumn{9}{|c|}{ Portfolios* } \\
\hline & $\mathrm{P} 1$ & $\mathrm{P} 2$ & P3 & P4 & P5 & P6 & P7 & P8 & P9 \\
\hline Strategic Alignment & $8 \%$ & $9 \%$ & $4 \%$ & $12 \%$ & $11 \%$ & $8 \%$ & $10 \%$ & $10 \%$ & $10 \%$ \\
\hline Achieving Portfolio Requirements & $8 \%$ & $9 \%$ & $8 \%$ & $8 \%$ & $2 \%$ & $10 \%$ & $5 \%$ & $5 \%$ & $2 \%$ \\
\hline Aligned with the Portfolio Plan & $3 \%$ & $5 \%$ & $10 \%$ & $10 \%$ & $1 \%$ & $5 \%$ & $7 \%$ & $4 \%$ & $5 \%$ \\
\hline Spatial Development & $3 \%$ & $5 \%$ & $3 \%$ & $4 \%$ & $8 \%$ & $8 \%$ & $6 \%$ & $5 \%$ & $3 \%$ \\
\hline Precedence of the Portfolio & $6 \%$ & $8 \%$ & $7 \%$ & $6 \%$ & $7 \%$ & $10 \%$ & $9 \%$ & $8 \%$ & $6 \%$ \\
\hline Social Feasibility & $8 \%$ & $10 \%$ & $2 \%$ & $8 \%$ & $9 \%$ & $6 \%$ & $10 \%$ & $8 \%$ & $10 \%$ \\
\hline Economic Feasibility & $9 \%$ & $10 \%$ & $10 \%$ & $5 \%$ & $4 \%$ & $7 \%$ & $2 \%$ & $10 \%$ & $8 \%$ \\
\hline Percentage Completion & $5 \%$ & $8 \%$ & $10 \%$ & $7 \%$ & $7 \%$ & $6 \%$ & $10 \%$ & $5 \%$ & $7 \%$ \\
\hline Financial Percentage Completion & $7 \%$ & $5 \%$ & $8 \%$ & $6 \%$ & $3 \%$ & $5 \%$ & $2 \%$ & $4 \%$ & $5 \%$ \\
\hline Payable Financial Dues & $4 \%$ & $4 \%$ & $5 \%$ & $5 \%$ & $9 \%$ & $10 \%$ & $8 \%$ & $8 \%$ & $10 \%$ \\
\hline Possibility of Cost Reducing & $10 \%$ & $8 \%$ & $7 \%$ & $4 \%$ & $5 \%$ & $7 \%$ & $6 \%$ & $10 \%$ & $4 \%$ \\
\hline Possibility of Converting to an Invest. & $4 \%$ & $5 \%$ & $9 \%$ & $8 \%$ & $6 \%$ & $7 \%$ & $10 \%$ & $4 \%$ & $10 \%$ \\
\hline Possibility of Tran. to the Oper. Budg. & $15 \%$ & $10 \%$ & $7 \%$ & $5 \%$ & $8 \%$ & $4 \%$ & $10 \%$ & $6 \%$ & $10 \%$ \\
\hline Problems of Project & $10 \%$ & $4 \%$ & $6 \%$ & $7 \%$ & $7 \%$ & $10 \%$ & $5 \%$ & $8 \%$ & $10 \%$ \\
\hline Total & $100 \%$ & $100 \%$ & $100 \%$ & $100 \%$ & $100 \%$ & $100 \%$ & $100 \%$ & $100 \%$ & $100 \%$ \\
\hline
\end{tabular}

*Portfolios and assessments are coded for data organization

the construction portfolios have many common characteristics to address many strategic objectives of the government sector. For each construction portfolio, the projects are in the same class; therefore, a project in the portfolio is submitted to the same valuation factors for the priority matrix. The data and results obtained from the field survey are summarised in tables to track the analysis of the study [28, 32].

The Iraqi government's financial budgets for the past ten years have been studied and analysed. Then, the researcher employed the theories of IPM with the support of administrative and financial cadres in the MOP. The study aimed to determine how to achieve optimal financial decisions that ensure project continuity. In addition to completing the stalled projects, this will help open it to the public as soon as possible.

The researcher classified the projects according to the sector as a portfolio with separate functional characteristics and independent requirements. Therefore, the strate- gic projects have two categories according to the funding resources:

Allocated budget projects have a predefined schedule (start and end information). The relationships between the activities are examined. For these portfolios, the researcher applied the concepts of resource levelling and smoothing, as shown in Eq. (1) [33]:

$$
(F . F .) \text { act. }=\min [(E . F .) a c t .-(E . S) . n e x t \text { act. })],
$$

where $F . F$. is the free-float activity within the project in the portfolio, E.F. is the early finish of non-critical path activities, and E.S. is defined as 'the minimum early start of sequential activities'.

Within a portfolio, free-float activities are applied to the momentum equation (Eq. (2)) [33]. Thus, the effectiveness of the activity is moved to the right position. The subsequent tables depict a summary of the results:

$$
\text { (I.F) act. }=\text { r.r. * }\left[\sum R^{\circ}-\sum \check{R}-m{ }^{\star} r . r .\right],
$$


Table 10: Results of the Studied projects

\begin{tabular}{|c|c|c|c|c|c|c|}
\hline Portfolio & Projects & Cost (MID) & $\begin{array}{l}\text { Payment } \\
(\%)\end{array}$ & $\begin{array}{c}\text { Complete } \\
(\%)\end{array}$ & $\begin{array}{l}\text { Assess. of } \\
\text { PM }\end{array}$ & $\begin{array}{l}\text { Decision (no. } \\
347) \text { of } 2015\end{array}$ \\
\hline \multirow{7}{*}{ 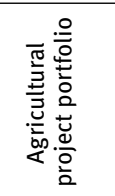 } & Lining the irrigation canals & 122904 & $4 \%$ & $18 \%$ & 52 & NE \\
\hline & Regulation of the river & 115750 & $68 \%$ & $68 \%$ & 60 & NE \\
\hline & Jay barrage & 100000 & $32 \%$ & $99.5 \%$ & 55 & NE \\
\hline & Closed irrigation project & 25424 & $93.27 \%$ & $99.7 \%$ & 74 & $\mathrm{NE}$ \\
\hline & Irrigation project & 23138 & $34 \%$ & $73 \%$ & 60 & NE \\
\hline & Expansion of the rivers & 100000 & $10 \%$ & $11 \%$ & 54 & NE \\
\hline & Construct modern villages & 359000 & $55.2 \%$ & $40 \%$ & 65 & $\mathrm{NE}$ \\
\hline \multirow{7}{*}{ 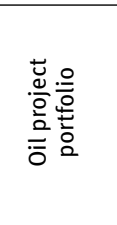 } & $\begin{array}{c}\text { Increase operational storage capacity for liquid gas/16 } \\
\text { ball tank }\end{array}$ & 183910 & $91 \%$ & $86.2 \%$ & 84 & Continuous \\
\hline & Water supply to the refinery & 104575 & $87.26 \%$ & $96.22 \%$ & 40 & Continuous \\
\hline & Development of the oil field & 533110 & $67.8 \%$ & $72.48 \%$ & 84 & Continuous \\
\hline & 14 in. pipe with pumping stations & 225000 & $80.2 \%$ & $70.7 \%$ & 78 & Continuous \\
\hline & Rehabilitation of gas pressing stations & 118000 & $39.79 \%$ & $61.01 \%$ & 71 & Continuous \\
\hline & Rehabilitation of K3 station & 96900 & $88.59 \%$ & $79 \%$ & 84 & Continuous \\
\hline & Development of oil field & 14163.3 & $0 \%$ & $0 \%$ & 69 & Continuous \\
\hline \multirow{7}{*}{ 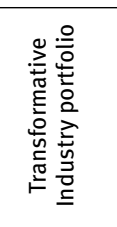 } & Project sealed lead-acid battery MF and solar batteries & 25000 & $3 \%$ & $77 \%$ & 55 & Continuous \\
\hline & Rehabilitate the company for petrochemical industries & 1200000 & $99 \%$ & $90 \%$ & 61 & Continuous \\
\hline & $\begin{array}{l}\text { Rehabilitate the fertiliser plant No. } 3 \text { with an electricity } \\
\text { conversion station }\end{array}$ & 105075 & $90 \%$ & $98 \%$ & 68 & Continuous \\
\hline & Rehabilitate the southern fertiliser plant IQ-P6 & 303790918 & $69 \%$ & $57 \%$ & 63 & Continuous \\
\hline & Geological survey, investigation and evaluation & 62500 & $69 \%$ & $56 \%$ & 32 & Continuous \\
\hline & Rehabilitate the electric stations in the northern region & 25231.917 & $0 \%$ & $0 \%$ & 83 & Continuous \\
\hline & Rehabilitate gaseous electric stations & 1237099.82 & $7 \%$ & $20 \%$ & 80 & Continuous \\
\hline \multirow{5}{*}{ 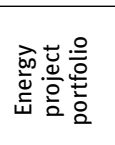 } & Rehabilitate the thermal electric station & 462554.429 & $22 \%$ & $50 \%$ & 80 & Continuous \\
\hline & Rehabilitate the hydropower electric stations & 72416.9028 & $32 \%$ & $74 \%$ & 80 & Continuous \\
\hline & Develop electrical networks at central regions & 1147636 & $11 \%$ & $5 \%$ & 67 & Continuous \\
\hline & Build electricity control centres in northern governorates & 63000 & $30 \%$ & $40 \%$ & 73 & Continuous \\
\hline & Develop electrical networks for city centres & 128 & $60 \%$ & $65 \%$ & 73 & Continuous \\
\hline \multirow{7}{*}{ 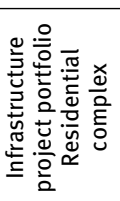 } & Residential complex & 70000 & $92 \%$ & $95 \%$ & 68 & Continuous \\
\hline & Residential complex & 55186 & $95 \%$ & $97 \%$ & 69 & Continuous \\
\hline & Infrastructure for developing scientific capacity & 138300 & $0.07 \%$ & $0.07 \%$ & 45 & NJ \\
\hline & Rehabilitate the infrastructure & 13000 & $0.96 \%$ & $0.95 \%$ & 82 & NJ \\
\hline & Rehabilitate the complex of the ministry & 43875 & $15 \%$ & $28 \%$ & 48 & Stalled \\
\hline & Establish a general hospital & 147500 & $61 \%$ & $83 \%$ & 69 & Continuous \\
\hline & Low income housing project & 74078.864 & $10 \%$ & $12 \%$ & 57 & Continuous \\
\hline \multirow{7}{*}{ 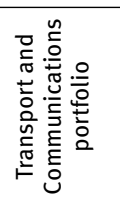 } & Develop telecommunication networks for the main cities & 155222 & $0.19 \%$ & $1 \%$ & 49 & Continuous \\
\hline & Optical cable network project (access network) & 216000 & $0.99 \%$ & $0.57 \%$ & 62 & Continuous \\
\hline & Develop satellite channel & 28098 & $0.03 \%$ & $0.6 \%$ & 0.23 & Continuous \\
\hline & West breakwater project of port & 951000 & $52 \%$ & $56 \%$ & 69 & Continuous \\
\hline & Railway & 57000 & $0.476 \%$ & $0.94 \%$ & 46 & Stalled \\
\hline & Rehabilitate airport & 23016.4 & $0.385 \%$ & $0.92 \%$ & 66 & Stalled \\
\hline & Rehabilitate airport & 59000 & $0.808 \%$ & $0.9 \%$ & 57 & Stalled \\
\hline \multirow{5}{*}{ 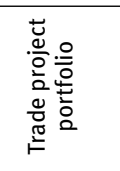 } & Install electromechanical equipment for silo & 23000 & $0 \%$ & $0.25 \%$ & 70 & Continuous \\
\hline & Rehabilitate horizontal high-capacity silos & 20000 & $0.27 \%$ & $0.58 \%$ & 71 & Continuous \\
\hline & $\begin{array}{l}\text { Rehabilitate electromechanical/control the two groups } \\
\text { (D\&E) }\end{array}$ & 26250 & $0.22 \%$ & $0.27 \%$ & 75 & Continuous \\
\hline & Construct a metal silo & 12000 & $0.46 \%$ & $0.6 \%$ & 67 & Continuous \\
\hline & Construct a metal silo & 12000 & $0.48 \%$ & $0.57 \%$ & 67 & Continuous \\
\hline \multirow{6}{*}{ 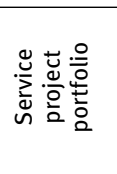 } & Maintain and operate sewage water treatment projects & 34014 & $99.9 \%$ & $85 \%$ & 82 & NE \\
\hline & Water purification plants/greater project & 847017 & $50.39 \%$ & $35.3 \%$ & 76 & $\mathrm{NE}$ \\
\hline & Water purification project & 50000 & $58 \%$ & $77.6 \%$ & 66 & $\mathrm{NE}$ \\
\hline & Water purification project & 15000 & $87 \%$ & $69 \%$ & 80 & $\mathrm{NE}$ \\
\hline & Water purification project & 73000 & $34 \%$ & $71.3 \%$ & 66 & NE \\
\hline & Land acquisition for water projects in governorates & 30000 & $26 \%$ & $26 \%$ & 75 & NE \\
\hline
\end{tabular}

*Projects are coded for data organisation. NE: not evaluated; NJ: not yet judged

where $I . F$. is the moment factor of the shifted activity within a project of the portfolio, r.r. is the resource rate of activity, and $m$ is the minimum number of moved cells.

Projects planned without a named budget show a community need. However, no financial capacity exists to establish these projects. Therefore, these projects are constructed depending on the revenues or internal operating amounts obtained by sponsoring institutions. An annual investment budget is usually used to complete these types of projects. Therefore, these projects have a known start time but no known end.
For this type of project, the researcher and competent cadres of MOP designed a methodology to assess the priorities of implementing the suspended projects called the priority matrix. The priority matrix prioritises each project package within the same portfolio. This methodology arranges the projects within a specific portfolio from the highest importance to the least importance. Within the portfolio, many projects await funding. The researcher developed priorities to allocate spending on the most important projects, to the least, according to evaluation axes related to the added value resulting from accelerating the implementation of each suspended project. Evaluation axes 
consist of 14 axes (strategic alignment, achieving portfolio requirements, aligned with the portfolio plan, spatial development, precedence of the portfolio, social feasibility, economic feasibility, percentage completion, financial percentage completion, payable financial dues, possibility of cost reducing, possibility of converting to an investment, possibility of transfer to operational budget, problems of project) whose total specific weight equals 100 per cent. Table 9 summarises the assessment using the priority matrix for each portfolio. Table 10 summarises the results.

The researcher applied the concept of resource levelling where determinants of resources are directly related to the costs following the budget. The researcher relied on amounts allocated by the country's annual budget, the 'investment budget'. The investment budget is usually spent on stalled projects suspended during the year (i.e. it is distributed to projects in need according to priority). Within a portfolio, the budget should determine what is required for specified resources for each time unit. The national economy is weak but not because of production, which covers not only domestic consumption but also diversification of exports, which is almost zero. Generally, financial elements of the public state budget depend on oil sector production. This is not surprising because the country contains the world's second-largest oil reserves. As a result, the revenues of oil account for about two-thirds of the country's GDP for all exports and fiscal revenue. The petroleum industry represents a pivotal element of the national economy, contributing to the country's GDP and growth and constituting $90 \%$ of the state revenue and almost all exports. Thus, the country's GDP comprises the production volume fluctuation and oil prices.

\section{Conclusions}

In the present study, a numerical analysis has been carried out to verify and evaluate the applicability of intelligent portfolio management theory in the Iraqi construction industry. The field study conducted by the researcher indicated that strategic departments of national construction industry in Iraq need modern and effective administrative systems, national bodies need to improve the reality of its' infrastructure by multi mid-term and long-term programmatic agenda strategies as five-year plans. Lack of professionalism in most of strategic management departments in Iraqi bodies, particularly with regard to financial allocation for service sectors as well as spread of corruption, nepotism and absence of transparency and justice. Priorities of financial resource allocation for infras- tructure financing usually subject to several social and political considerations and personal convictions sometimes by the senior administrations in national construction industry. So, adopting intelligent portfolio management concepts' in national institutions of the construction industry to solve state budget shortage, enhance enterprises' efficiency for resource consumption. Also, this will support, financial decisions taken by senior management departments. The current study focused on settlement strategies regarding the risks of the national construction industry as effective solutions to the existing stalled construction projects. The increased use of portfolios is a means to share construction risks among construction projects. Construction institutions have adopted the use of portfolios for relatively low cost initial capital construction projects. The portfolio concept for such projects is oriented differently, where project importance and priority lead to new considerations when adopting the portfolio management theory in national construction industry.

\section{References}

[1] Kangari R, Riggs LS. Portfolio management in construction. Construct Manag Econ. 1988 Jun;6(2):161-9.

[2] Gann DM, Salter AJ. Innovation in project-based, serviceenhanced firms: the construction of complex products and systems. Res Policy. 2000 Aug;29(7-8):955-72.

[3] Khalaf, T. Z., Çağlar, H., Çağlar, A., \& Hanoon, A. N. (2020). Particle Swarm Optimization Based Approach for Estimation of Costs and Duration of Construction Projects. Civil Engineering Journal, 6(2), 384-401. https://doi.org/10.28991/cej-202003091478.

[4] Omar, N. S., Hatem, W. A., \& Najy, H. I. (2019). Predictive Modeling for Developing Maintenance Management in Construction Projects. Civil Engineering Journal, 5(4), 892-900. https:// doi.org/10.28991/cej-2019-03091297.

[5] Hatem, W. A., Abd, A. M., \& Abbas, N. N. (2017). Testing a Measurement Model of BIM Potential Benefits in Iraqi Construction Projects. Civil Engineering Journal, 3(12). DOI: https:// doi.org/10.28991/cej-030963.

[6] Abed, H. R., Hatem, W. A., \& Jasim, N. A. (2019). Adopting BIM Technology in Fall Prevention Plans. Civil Engineering Journal, 5(10), 2270-2281. https://doi.org/10.28991/cej-2019. 03091410.

[7] Toor SR, Ogunlana SO. Critical COMs of success in large-scale construction projects: evidence from Thailand construction industry. Int J Proj Manag. 2008 May;26(4):420-30.

[8] Dashti MA, Farjami Y, Vedadi A, Anisseh M. 'Implementation of particle swarm optimization in construction of optimal risky portfolios', 2007 IEEE International Conference on Industrial Engineering and Engineering Management, Dec. 2007. DOI: https://doi.org/10.1109/IEEM.2007.4419303.

[9] Fabozzi FJ, Gupta F, Markowitz HM. The legacy of modern portfolio theory. J Invest. 2002 Aug;11(3):7-22. 
[10] Rajegopal S. What is the role of leadership in successful delivery execution. Portfolio Management; 2013. pp. 170-7.

[11] Cooper RG, Edgett SJ, Kleinschmidt EJ. New product portfolio management: practices and performance. J Prod Innov Manage. 1992 Jul;16(4):333-51.

[12] Guo N, Yu SW. The necessity of project portfolio management in the construction industry of China mainland. Appl Mech Mater. 2013 Aug;357-360:2238-41.

[13] Meskendahl S. The influence of business strategy on project portfolio management and its success-A conceptual framework. Int J Proj Manag. 2010 Dec;28(8):807-17.

[14] Blomquist T, Müller R. Practices, roles, and responsibilities of middle managers in program and portfolio management. Proj Manage J. 2006 Mar;37(1):52-66.

[15] Thiry M. 'For DAD': A programme management life-cycle process. Int J Proj Manag. 2004 Apr;22(3):245-52.

[16] 'IEEE Guide - Adoption of the Project Management Institute (PMI(R)) standard. A guide to the Project Management Body of Knowledge (PMBOK(R) Guide)fourth edition'.

[17] Meskendahl S. The influence of business strategy on project portfolio management and its success-A conceptual framework. Int J Proj Manag. 2010 Dec;28(8):807-17.

[18] Junnonen JM. Junnonen, 'Strategy formation in construction firms'. Eng Construct Architect Manag. 1998 Jun;5(2):107-14.

[19] Chinowsky PS, Meredith JE. Strategic management in construction. J Constr Eng Manage. 2000 Jan;126(1):1-9.

[20] Pries F, Janszen F. Innovation in the construction industry: the dominant role of the environment. Construct Manag Econ. 1995 Jan;13(1):43-51.

[21] Construction project leadership. Management of Construction Projects. 2017;(Mar):274-86.

[22] K. A. Artto and P. H. Dietrich, 'Strategic business management through multiple projects', The Wiley Guide to Managing Projects, Nov. 2007, ch.7, pp. 144-176.
[23] Subramaniam A. (2009), Holistic approach to manage strategic initiatives, [Project Portfolio Management] Available: https:// www.slideshare.net/anandsubramaniam/project-portfolio-m anagement, (Accessed July 12, 2019)

[24] Kaiser MG, El Arbi F, Ahlemann F. Successful project portfolio management beyond project selection techniques: understanding the role of structural alignment. Int J Proj Manag. 2015 Jan;33(1):126-39.

[25] L. Romano, 'Adaptive portfolio management', Advances in IT Personnel and Project Management, pp. 153-177. https:// doi.org/10.4018/978-1-5225-2151-8.ch006.

[26] The portfolio management PMO and metrics. Project Management Metrics, KPIs, and Dashboards. 2017;(Sep):413-23.

[27] Newnan DG. 'A review of: 'Engineeringeconomy: A behavioralapproach by Anthony Tarquin and Leland Blank'. Eng Econ. 1979 Jan;25(1):75-7.

[28] Fabozzi FJ, Gupta F, Markowitz HM. The legacy of modern portfolio theory. J Invest. 2002 Aug;11(3):7-22.

[29] Report of Iraqi Ministry of Planning, Central Statistical Organization, Directorate of Standard Numbers and Department of Sectors Planning.

[30] Presidency of Council of Ministers, National Investment Commission, Major strategic projects available for investment according to sector.

[31] Ministry of Finance, Department of Budget.

[32] Economic visions of the National Investment Commission and the report of economic reform policy for the next five years.

[33] Pilcher R. Principles of construction management. McGraw-Hill College; 1992.[Google Scholar]. 